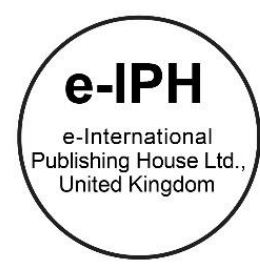

\title{
Contribution of the Built Environment towards Elderlies' Quality of Life and Risk of Falling
}

\author{
Nurul Liyana Hanapi ${ }^{1}$, Sabarinah Sheikh Ahmad², Azli Abd Razak³, Norhati Ibrahim ${ }^{4}$ \\ 1Department of Architecture, Faculty of Engineering \& Built Environment, \\ SEGi University, 47810, Selangor Malaysia. \\ ${ }^{2,4}$ Faculty of Architecture, Planning and Surveying, \\ Universiti Teknologi MARA (UiTM), Puncak Alam 42300, Selangor Malaysia \\ ${ }^{3}$ Faculty of Mechanical Engineering, \\ Universiti Teknologi MARA (UiTM), Shah Alam 40450, Selangor, Malaysia
}

liyanahanapi@segi.edu.my, sabar643@uitm.edu.my, azlirazak@uitm.edu.my,norhati@uitm.edu.my Tel: +60146291506

\begin{abstract}
Recent study trends on elderlies range from improving their quality of life to reducing the risk of falling. This paper investigates current concerns on the risk of any untoward fall or injury of elderly residents in public housing due to the rising number of the elderly population. This study aims to analyze published literature with a focus on finding a non-semantic relation on the built environment with the elderly quality of life and risk of falling. Results show that a pleasant environment could introduce social activities in which significantly improves the quality of life and reduce fall risk among the elderly population.
\end{abstract}

Keywords: elderly; quality of life; fall risk; environment.

eISSN: 2398-4287 @ 2019. The Authors. Published for AMER ABRA cE-Bs by e-International Publishing House, Ltd., UK. This is an open access article under the CC BYNC-ND license (http://creativecommons.org/licenses/by-nc-nd/4.0/). Peer-review under responsibility of AMER (Association of Malaysian Environment-Behaviour Researchers), ABRA (Association of Behavioural Researchers on Asians) and cE-Bs (Centre for Environment-Behaviour Studies), Faculty of Architecture, Planning \& Surveying, Universiti Teknologi MARA, Malaysia.

DOI: https://doi.org/10.21834/e-bpj.v4i12.1939

\subsection{Introduction}

Malaysia is currently facing an increase in its population, especially in its cities. Statistics taken by the Department of Statistics Malaysia (2010) showed that Kuala Lumpur has the highest population density in the nation with 6,891 people per square kilometre followed by Putrajaya and Pulau Pinang with densities of 1,478 and 1,490 people per square kilometre, respectively. Even though the density level is closely associated with the size of these states, Selangor, which has the most significant state size amongst the three, has only 674 people per square kilometre because most of its population scattered around the city centre.

The number of living quarters and households has increased by 0.1 million from its 2016 figures wherein 2017, living quarters and houses totalled at 8.5 million and 7.7 million respectively, with an average household increase of $4.06 \%$ (Department of Statistics Malaysia, 2010). Malaysia is reaching the status of an ageing population country by 2020, with the percentage of elderly population exceeding $7.2 \%$. By the year 2040 , the rate could reach up to $15 \%$ of the total population. Such an increase in the elderly population marks a change in the median ages of Malaysia; in 2017, the median age was 28.3 years, but in 2040 the median age will be 38.3 years which indicates an increase of 10 years in the median age over only 23 years. All the data discussed in this section gathered from the statistics provided by the United Nations Population Division and the Department of Statistics Malaysia.

The rapid increase of urban population is evident with the rise of multi-storey residential buildings. In turn, the growth of the older people living in multi-storey buildings has raised concerns on the quality of life amongst the elderly. Plus, with the increment of the

eISSN: 2398-4287 @ 2019. The Authors. Published for AMER ABRA cE-Bs by e-International Publishing House, Ltd., UK. This is an open access article under the CC BYNC-ND license (http://creativecommons.org/licenses/by-nc-nd/4.0). Peer-review under responsibility of AMER (Association of Malaysian Environment-Behaviour Researchers), ABRA (Association of Behavioural Researchers on Asians) and cE-Bs (Centre for Environment-Behaviour Studies), Faculty of Architecture, Planning \& Surveying, Universiti Teknologi MARA, Malaysia.

DOI: https://doi.org/10.21834/e-bpj.v4i12.1939 
elderly causing interest in the fall risk, which could lead to reducing their quality of life. Many studies highlighted on the elderly quality of life and fall prevention, but the relation with the built environment with both issues not adequately addressed.

Thus, this study aims to analyze the published literature with a focusing on finding a non-semantic relation on the built environment with the elderly quality of life and risk of falling. The main objective is to evaluate a significant factor that could contribute to improving the elderlies quality of life.

\subsection{Literature Review}

As discussed in the preceding section, the population pattern in Malaysia is slowly shifting to having a much bigger composition of the elderly. Although the age for one to qualify as an elder varies, the baseline for this age group (ageing of 60 and above) is consistent. While the World Health Organization defines the elderly to be 65 years old and above; the United Nations World Assembly on Ageing held in Vienna in 1982 described an elder to be anyone of the age of 60 and above (Hamid, 2015; Othman \& Fadzil, 2015; Rizawati, 2008). Malaysia has adopted the demarcation recommended by the UN (Mohammad, \& Abbas, 2012). Therefore, the elderlies in Malaysia include those aged 60 years and above. The term "senior citizen" or "Warga Emas" used to address this group of people individually. Additionally, the age of 60 marks the compulsory retirement age for workers in the government sector (Abbas \& Saruwono, 2012).

Following the escalating number of the elderly population, many studies focusing on the needs of these elderlies. The trending topics projected by most recent studies ranged from improving the elderlies' quality of life to reducing the risk of falling among elderly residents. This study made upon the latest concerns on the increasing number of the elderly population as preventing injury among the elderlies is essential to avoid an increase in hospitalization and disabilities. Subsequent parts of this paper studies on both issues.

\subsection{Methodology}

The research methodology applied was a content analysis of past literature to determine the trend of research in the areas mentioned. The data searched through online search from Science Directs, Google Scholar and other search engines. The term elderly, together with the term quality of life and fall risk, was used in search strategies to finds related article from 2006 until the latest published article. Then, analysed the data obtained using ATLAS.ti 8 to identify the trends in the areas mentioned and find the non-semantic linkage between the materials. Only studies that limited to the built environment are chosen and analysed as another article might highlighting another factor which is not related to the built environment.

\subsection{Findings}

From the data collected, two apparent study trends found concerning the increase of the elderly population, which are the quality of life of the elderly and fall prevention amongst the elderly. Concerns mainly focused on elderlies' daily activities; however, concerns on the safety of the elderly during an emergency also need to be taken into account.

\subsection{Quality of Life of the Elderly Population}

It has predicted a profound upsurge in the number of elderlies, concerning their awareness towards the environment, have started to be raised in many studies as listed in Table 1.

Table 1 List of Studies on Quality of Life (QoL) of the Elderly Population

\begin{tabular}{|c|c|c|c|}
\hline Year & Author & Country & Findings \\
\hline \multirow[t]{4}{*}{2014} & Stenhagen et al. & Malaysia & $\begin{array}{l}\text { Elderly evacuees who are prone to falls have low satisfaction towards } \\
\text { the environment, which in turn might become another factor } \\
\text { contributing to the risk of falling. }\end{array}$ \\
\hline & Mauceri \& Marco & Malaysia & $\begin{array}{l}\text { The psychosocial of elderly evacuees in association with the quality of } \\
\text { life yielded a positive correlation between self-efficacy and negative } \\
\text { emotions among this particular group. }\end{array}$ \\
\hline & Kamarudin et al. & Malaysia & $\begin{array}{l}\text { A study on public building facilities which included the elderly as part } \\
\text { of the study group highlighted that the implementation of practices and } \\
\text { legislation for the disabled was lacking in public buildings. }\end{array}$ \\
\hline & Wong \& Musa & Malaysia & $\begin{array}{l}\text { Identified the reasons for many elderlies choosing Malaysia as their } \\
\text { second home. Although other studies had conveyed mixed opinions } \\
\text { on the satisfaction level of elderly evacuees, this study had gained } \\
\text { positive feedback from international retirees. }\end{array}$ \\
\hline \multirow[t]{2}{*}{2015} & Othman \& Fadzil & Malaysia & $\begin{array}{l}\text { The study on the outdoor environment of care centres found a } \\
\text { correlation between decently designed outdoor space and the well- } \\
\text { being of elderly evacuees. }\end{array}$ \\
\hline & $\begin{array}{l}\text { Pramitasari \& } \\
\text { Sarwadi }\end{array}$ & Indonesia & $\begin{array}{l}\text { The study on QoL of the elderlies was incorporated with the built } \\
\text { environment in a dense community to test the sufficiency of facilities } \\
\text { provided in Yogyakarta }\end{array}$ \\
\hline 2016 & Onunkwor et al. & Malaysia & $\begin{array}{l}\text { Both social support and the physical factor contribute to the quality of } \\
\text { life, but emphasis need to be given to social support intervention. }\end{array}$ \\
\hline
\end{tabular}




\begin{tabular}{|c|c|c|c|}
\hline & Dahlan et al. & Malaysia & $\begin{array}{l}\text { Good environment factors facilitate the opportunity to socialize which } \\
\text { increases the social factor. }\end{array}$ \\
\hline & Sajin et al. & Malaysia & $\begin{array}{l}\text { Leisure facilities help to increase engagement among the elderly which } \\
\text { increases the social factor. }\end{array}$ \\
\hline \multirow[t]{2}{*}{2017} & Dahlan \& Ibrahim & Malaysia & $\begin{array}{l}\text { Increased activities give a significant improvement in Quality of Life } \\
\text { amongst the elderly in the institution. }\end{array}$ \\
\hline & Tobi et al. & Malaysia & $\begin{array}{l}\text { The built environment plays a role in defining the quality of life. Proper } \\
\text { accessibilities and basic needs of the elderly have a positive outcome } \\
\text { and become key factors supporting the independent living lifestyle } \\
\text { amongst the elderly. }\end{array}$ \\
\hline \multirow[t]{2}{*}{2018} & Hamzah \& Ismail & Malaysia & $\begin{array}{l}\text { Engagement in voluntary activities could increase the social factor and } \\
\text { in turn, significantly increase life satisfaction. }\end{array}$ \\
\hline & Marzo et al. & Malaysia & $\begin{array}{l}\text { Neutral satisfaction towards the quality of life but high scores on the } \\
\text { social and physical factors which need to be strengthened to improve } \\
\text { quality of life. }\end{array}$ \\
\hline 2019 & Osman \& Ismail & Malaysia & $\begin{array}{l}\text { Focus on personal and social needs increase the quality of life among } \\
\text { the elderly. Financial status and level of income were the least } \\
\text { contributing factors towards positive wellbeing. }\end{array}$ \\
\hline
\end{tabular}

Many studies have found low satisfaction levels in terms of elderlies' quality of life not meet their current environment needs. The satisfaction of requirements is not only limited to safety and physiological needs, but also the need for relationship, development, and fulfilment. In summary, the built environment has become a significant factor in determining the quality of life of elderly residents. A pleasant atmosphere is not only able to increase their satisfaction levels, but also leads to positive health and psychology. A friendly environment also helps to increase social interaction amongst the elderly which significantly increases the social factor for them. Review of past studies on building evacuations showed that although low satisfaction levels have recorded among elderly evacuees especially those who are disabled, Malaysia is still seen as a suitable place for international retirees for it renders self-fulfilment for them. It can thus take as a contributing factor to the increase in the number of elderly evacuees in Malaysia. The needs of elderly evacuees in public housing during emergencies have yet to receive much consideration. Thus calls for more emphasis to be dedicated to this group to ensure building evacuation efficacy. More accounts should give to particular population groups such as elderly evacuees and senior citizens through the provision of facilities required for evacuation (Sadri, Ukkusuri \& Gladwin, 2017).

\subsection{Risk of Falling Among Elderly Occupants}

Fall risk among elderly occupants in public buildings has become a massive topic since the predicted increment of the elderly population has become a significant public health concern. Since then, the number of researches in similar areas has increased, signifying that awareness towards fall risk among elderly evacuees has improved. Table 2 summarises the trends observed from these studies

Table 2 shows that much emphasis given to the prevalence and factors of fall risk. It is to determine the category of elderlies who are more prone to fall risk (Rubenstein, 2006; Shariff, Krishnan, Shamsul, Ahmad, \& Visvanathan, 2008; Swanenburg, de Bruin, Uebelhart, \& Mulder, 2010; Rowe, 2011). Only a few studies have looked into strategies for prevention or reduction of fall risk among elderly evacuees, while none of the studies had attempted to uncover the challenges created post-fall incident (Rubenstein, 2006; Rowe, 2011).

The trend of determining and understanding fall risk factors has continued for years; only after a while had some studies started to incorporate strategies to minimise fall risk after foreseeing the challenges faced due to falls. Ambrose, Paul, and Hausdorff (2013) and Greenberg (2012) were among the earliest who observed the challenges elderly evacuees faced in post-fall incidences.

Table 2 List of Studies on Fall Risk and their Scope of Study

\begin{tabular}{|c|c|c|c|c|c|}
\hline Year & Author & Country & Challenges & $\begin{array}{c}\text { Prevalence \& } \\
\text { Risk factor }\end{array}$ & Strategies \\
\hline 2006 & Rubenstein & America & - & $x$ & $x$ \\
\hline 2008 & Shariff et al. & Malaysia & - & $x$ & - \\
\hline 2010 & Swanenburg et al. & Switzerland & - & $x$ & - \\
\hline \multirow[t]{2}{*}{2011} & Kadir \& Hasim & Malaysia & - & $x$ & - \\
\hline & Rowe & America & - & $x$ & $x$ \\
\hline \multirow[t]{2}{*}{2012} & Momtaz et al. & Malaysia & - & $x$ & - \\
\hline & Greenberg & America & $x$ & - & $x$ \\
\hline \multirow[t]{2}{*}{2013} & Zijlstra et al. & Netherlands & - & $x$ & $x$ \\
\hline & Ambrose et al. & America & $x$ & $x$ & $x$ \\
\hline \multirow[t]{5}{*}{2014} & Stenhagen et al. & Sweden & - & $x$ & - \\
\hline & Lim et al. & Malaysia & - & $x$ & - \\
\hline & Tan et al. & Malaysia & $x$ & - & $x$ \\
\hline & Clemson et al. & Australia & $x$ & $x$ & - \\
\hline & Tuunainen et al. & Finland & $x$ & $x$ & - \\
\hline
\end{tabular}




\begin{tabular}{|c|c|c|c|c|c|}
\hline & Gelbard et al. & America & $\mathrm{x}$ & - & - \\
\hline \multirow[t]{11}{*}{2015} & Keall et al. & New Zealand & - & - & $x$ \\
\hline & Montali et al. & Italy & $\mathrm{X}$ & $x$ & $x$ \\
\hline & Abu Samah et al. & Malaysia & - & $x$ & - \\
\hline & Alekna et al. & Lithuania & $\mathrm{X}$ & - & - \\
\hline & Luk et al. & Hong Kong & - & - & $x$ \\
\hline & Kim et al. & Korea & - & - & $x$ \\
\hline & Smee et al. & Australia & - & $x$ & - \\
\hline & Eriksen et al. & America & $x$ & - & $\mathrm{x}$ \\
\hline & Pi et al. & China & $\mathrm{X}$ & $x$ & $x$ \\
\hline & Soto-Varela et al. & Spain & - & $x$ & $x$ \\
\hline & Bruce et al. & Australia & - & $x$ & - \\
\hline \multirow[t]{5}{*}{2016} & Hatamabadi et al. & Iran & - & - & $x$ \\
\hline & $\begin{array}{l}\text { Thiwabhorn Thaweewannakij } \\
\text { et al. }\end{array}$ & Thailand & - & $x$ & $\mathrm{X}$ \\
\hline & Callis & America & $\mathrm{X}$ & $x$ & $\mathrm{X}$ \\
\hline & Leszczyńska et al. & Poland & $x$ & - & $x$ \\
\hline & Marques-Vieira et al. & Spain & - & - & $x$ \\
\hline \multirow[t]{4}{*}{2019} & Forth \& Aiden & USA & - & $x$ & $x$ \\
\hline & Thomas et al. & Spain & - & - & $x$ \\
\hline & Khalifa & & - & - & $x$ \\
\hline & Van Than et al. & & - & - & $\mathrm{x}$ \\
\hline
\end{tabular}

Since there are strong justifications on the prevalence of fall risk, as presented in previous studies, in the year 2015 witnessed a shift in study trends, as shown in Table 2. Fall prevention strategies dominated the pattern of the research scope, as many studies tried to find the best strategies to mitigate fall risk among elderly evacuees. However, there were a few pioneer studies in 2014, which highlighted the challenges faced in reducing the issue of fall prevention. The number of studies on this topic predicted to increase as the demography of the population experiences profound growth in its elderly generation.

One of the challenges faced by the researchers is trying to find ways to reduce the number of casualties due to fall incidents (Tuunainen et al., 2014; Montali et al., 2015; Pi et al., 2015; Callis, 2016). Even if one survives from a fall incident, the side effects of the event not only would be detrimental to the person's physiology and psychology but also family members and caregivers. Adverse effects of a fall incident on the psychology of an individual include trauma, depression, anxiety, social isolation, and reduced quality of life.

The impacts of a fall incident on a person's physiology, on the other hand, include functional decline and disability, which subsequently lead to a reduction in physical activity. Fall incidents, as shown by Pi et al. (2015) not only place a burden on the victims but also to those around them, including family and society. The fall nonetheless has the most significant impact on the deterioration of the quality of life of the elderly himself.

Fall risk generally increases as the factors linked to the threat are amplified. People with one or two factors possess a $27 \%$ risk of falls, whereas those with more than two factors exposed to the risk of falls at as high as 78\% (Rowe, 2011). Therefore, emphasis on the need for a barrier-free environment to be adopted in both indoor and outdoor settings to mitigate the issue of accidental falls among elderly evacuees should be given priority as proposed by many studies (Abbas \& Saruwono, 2012; Kamarudin et al., 2014). In 2015, many studies started to test out strategies to reduce fall risk. These strategies involve simple procedures ranging from increasing the elderlies' physical activities to the application of detectors and sensors to track the possibility of falls.

Considering that elderly evacuee exposed to the risk of falling even in typical situations, a situation of emergency hence exposes this group to a more significant risk of morbidity and casualties. Many studies conducted had mostly focused on the risk of falling among elderly evacuees in normal conditions which presents a gap in knowledge on the risk of falls among elderly evacuees when they encounter panic or emergencies. Since elderly evacuees are prone to falling, the main concern is on their safety when in crowd stampedes of high density (this is also often associated with panic behaviour that believed to be able to cause great danger). 


\subsection{Discussion}

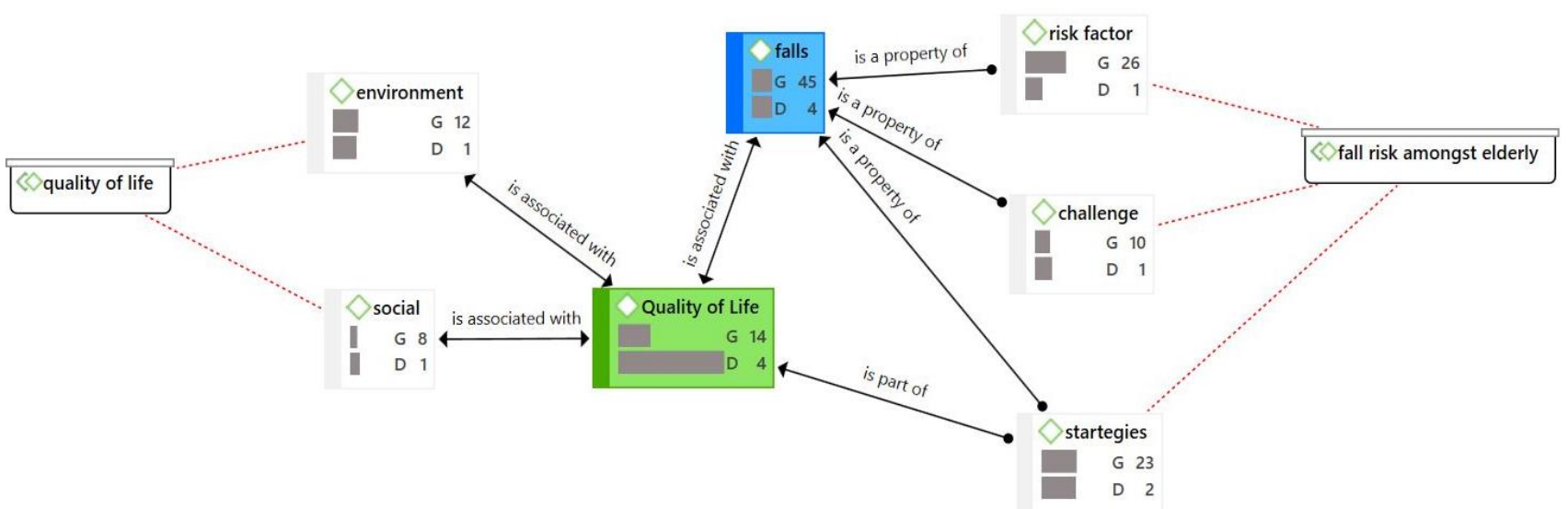

Fig. 1: Visualisation of the non-semantic linkages between the various elements of the project

(Source:Data analysis from ATLAS.ti 8)

Figure 1 presents a visualisation of the non-semantic linkages between the different elements that have highlighted earlier. The analysis shows that the social and environmental factors highly contribute to the quality of life amongst the elderly population. The environmental factor is the most grounded as it linked to 12 quotations compared to the social factor, which only quoted eight times which can be associated with the importance of environmental factors as it could also contribute to social factors. All the quoted element are from the literature reviewed in these studies. As for the fall risk amongst elderly residents, many studies highlighted the risk factor and strategies for fall prevention, where both received 26 quotations and 23 quotations. Amongst the risk factor discusses can be related to the environmental factor which affecting the elderly quality of life. As for the challenge, ten quotes have made to highlight the difficulties faced by mitigating the fall issues of the elderly.

The published literature review is mainly highlighting the social factor and environmental factor as a two separate solution towards improving the quality of life. From the analysis, it found that the environmental factor could significantly contribute to socialising activities amongst the elderly. It also found that most studies that highlighted the risk factor, challenge and strategies also relates to the built environment, which significantly contributes to the risk of falling. Besides built environment factor, the internal factor, which is the psychological and physiological factor of the elderly becomes the cause of fall risk. Their psychological and physiological element of the elderly could be improved if the built environment can be designed in which increased the social activity amongst the elderly, which enhances their lifestyle and quality of life.

\subsection{Conclusion and Recommendations}

In conclusion, improvements in the environmental factor contributing to an increase in the social factor which results in improvements in the elderlies' quality of life. As for the issue of fall risk, it commonly associated with the elderlies' overall health and the environmental factor that may contribute to a higher incidence of falls amongst elderly occupants which hence proves that the environmental factor can increase the quality of life and decrease the risk of falls amongst the elderly. Its automatically means that the environmental factor linked with the elderlies' quality of life and fall prevention. The social factor is the most significant factor that could improve the quality of life and fall risk. Thus, designing a built environment of the elderlies should focus on enhancing or encouraging socialised activities among the elderly. Future studies should, therefore, focus on the effectiveness of environmental conditions towards both the elderlies' quality of life and prevention of falls as only a small number of studies have been conducted in Malaysia, and all the related article found were separated.

\section{Acknowledgements}

This study is supported by the Ministry of Education under the Mybrain15 scholarship award and the seminar presentation is funded by SEGi University Sdn. Bhd. Special thanks to Thunderhead Engineering for providing free license for the Pathfinder software.

\section{References}

Aibar-Almazán, A., Martínez-Amat, A., Cruz-Díaz, D., De la Torre-Cruz, M. J., Jiménez-García, J. D., Zagalaz-Anula, N., ... \& Hita-Contreras, F. (2019). Effects of Pilates on Fall Risk Factors in Community-Dwelling Elderly Women: A Randomized, Controlled Trial. European journal of sport science, 1-9.

Ambrose, A. F., Paul, G., \& Hausdorff, J. M. (2013). Risk factors for falls among older adults: a review of the literature. Maturitas, 75(1), 51-61. 
Hanapi, N.L., et.al., / $8^{\text {th }}$ AcE-Bs2019Langkawilsland, Malaysia 18-19 Dec 2019 / E-BPJ, 4(12), Dec. 2019 (pp.101-107)

Callis, N. (2016). Falls Prevention: Identification of Predictive fall risk factors. Applied nursing research, 29, 53-58.

Dahlan, A., Ibrahim, S., \& Anwar, S. (2014). Engagement in Activity of Interest And Quality of Life Amongst Institutionalized Elderly People in Malaysia. Indian Journal of Health \& Wellbeing, 5(2).

Department of Statistics Malaysia. (2019). Population and Housing Census of Malaysia, 2019. Economic Characteristics of the Population, 2019. Putrajaya, Malaysia. Reviewed on $6^{\text {th }}$ October 2019

Dujardin, C., Lorant, V., \& Thomas, I. (2014). Self-Assessed Health of Elderly People in Brussels: Does the Built Environment Matter? Health \& place, $27,59-67$.

Forth, K., \& Aiden, E. L. (2019). U.S. Patent No. 10,307,084. Washington, DC: U.S. Patent and Trademark Office. Reviewed on 6th October 2019.

Greenberg, S. A. (2012). Analysis of measurement tools of fear of falling for high-risk, community-dwelling older adults. Clinical Nursing Research, 21(1), 113-130.

Hamzah, N. S., \& Ismail, R. (2018). Voluntarism and Life Satisfaction among Elderly in Rural Perak. International Journal of Academic Research in Business and Social Sciences, 8(4), 1036-1044.

Hatamabadi, H. R., Sum, S., Tabatabaey, A., \& Sabbaghi, M. (2016). Emergency Department Management of fall in the Elderly: A Clinical Audit and Suggestions for Improvement. International emergency nursing, 24, 2-8.

Marzo, R. R., Ahmad, A., Naing, T. W., bin Salleh, H., Hui, L., Raakeswar, A., ... \& Uu, W. K. (2018). Caring for Quality of Life among Elderly in Bandar Maharani, Muar, Johor, Malaysia. Academic Journal of Life Sciences, 4(4), 18-26.

Kadir, A. A., \& Hasim, H. (2011). Prevalence of falls in elderly men with diabetes in Diabetic Clinic Universiti Sains Malaysia Hospital, Malaysia. Journal of Men's Health, 8(S1), S91-S93.

Kamarudin, H., Ariff, N. M., Ismail, W. W., Bakri, A. F., \& Ithnin, Z. (2014). Malaysian Scenario on Access and Facilities for Persons with Disabilities: A Literature Review. In MATEC Web of Conferences (Vol. 15, p. 01019). EDP Sciences.

Khalifa, M. (2019). Improving Patient Safety by Reducing Falls in Hospitals among the Elderly: A Review of Successful Strategies. Studies in health technology and informatics, 262, 340-343.

Leszczyńska, A., Daniszewska, B., Pruszyńska, M., Przedborska, A., Hadała, M., \& Raczkowski, J. W. (2016). Effects of a Health Improvement Programme on Quality of Life in Elderly People after Falls. Polish annals of medicine, 23(2), 129-134

Marques-Vieira, C. M. A., Sousa, L. M. M., Severino, S., Sousa, L., \& Caldeira, S. (2016). Cross-Cultural Validation of the Falls Efficacy Scale International in Elderly: Systematic Literature Review. Journal of Clinical Gerontology and Geriatrics, 7(3), 72-76.

Marzo, R. R., Ahmad, A., Naing, T. W., bin Salleh, H., Hui, L., Raakeswar, A., .. \& Uu, W. K. (2018). Caring for Quality of Life among Elderly in Bandar Maharani, Muar, Johor, Malaysia. Academic Journal of Life Sciences, 4(4), 18-26.

Mauceri, M., \& Di Marco, O. L. G. (2014). Psychosocial dimensions of Quality of Life among Elders: A Research of the Italian and Spanish elderly. Procedia-Social and Behavioral Sciences, 116, 1651-1655

Momtaz, Y. A., Hamid, T. A., \& Ibrahim, R. (2012). Unmet needs among disabled elderly Malaysians. Social Science \& Medicine, 75(5), 859-863.

Onunkwor, O. F., Al-Dubai, S. A. R., George, P. P., Arokiasamy, J., Yadav, H., Barua, A., \& Shuaibu, H. O. (2016). A Cross-Sectional Study on Quality of Life Among the Elderly in Non-Governmental Organizations' Elderly Homes in Kuala Lumpur. Health and quality of life outcomes, 14(1), 6.

Osman, U. A. N., \& Ismail, R. (2019). The Factors Influencing the Level of Well-being among Elderly in Selangor, Malaysia. International Journal of Academic Research in Business and Social Sciences, 9(3).

Osman, U. A. N., \& Ismail, R. (2018). The Factors Influencing the Level of Well-being among Elderly in Selangor. Management Research Journal, 7, 146-156.

Othman, A. R., \& Fadzil, F. (2015). Influence of Outdoor Space to the Elderly Wellbeing in a Typical Care Centre. Procedia-Social and Behavioral Sciences, 170, $320-$ 329 .

Pramitasari, D., \& Sarwadi, A. (2015). A Study on Elderly's Going Out Activities and Environment Facilities. Procedia Environmental Sciences, 28, 315-323.

Rowe, R. J. (2011). Fall prevention: Core characteristics and practical interventions. Home Health Care Management \& Practice, 23(1), 20-26.

Rubenstein, L. Z. (2006). Falls in older people: epidemiology, risk factors and strategies for prevention. Age and ageing, 35(suppl_2), ii37-ii41.

Sajin, N. B., Dahlan, A., \& Ibrahim, S. A. S. (2016). Quality of life and Leisure Participation Amongst Malay Older People in the Institution. Procedia-Social and Behavioral Sciences, 234, 83-89.

Shariff, S., Krishnan, R., Shamsul, A., Zaiton, A., \& Visvanathan, R. (2008). Prevalence of falls among older people attending a primary care clinic in Kuala Lumpur, Malaysia. J Community Health, 14(1), 11-16.

Stenhagen, M., Ekström, H., Nordell, E., \& Elmståhl, S. (2014). Accidental Falls, Health-Related Quality of Life and Life Satisfaction: A Prospective Study of the General Elderly Population. Archives of gerontology and geriatrics, 58(1), 95-100.

Swanenburg, J., de Bruin, E. D., Uebelhart, D., \& Mulder, T. (2010). Falls prediction in elderly people: a 1-year prospective study. Gait \& posture, 31(3), 317-321.

Thaweewannakij, T., Suwannarat, P., Mato, L., \& Amatachaya, S. (2016). Functional Ability and Health Status of Community-Dwelling Late Age Elderly People With and Without a History of Falls. Hong Kong Physiotherapy Journal, 34, 1-9. 


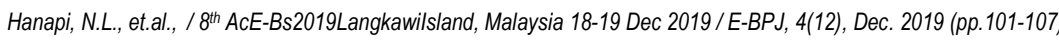

Thomas, E., Battaglia, G., Patti, A., Brusa, J., Leonardi, V., Palma, A., \& Bellafiore, M. (2019). Physical Activity Programs for Balance and Fall Prevention in Elderly: A Systematic Review. Medicine, 98(27).

Tobi, S. M., Fathi, M. S., \& Amaratunga, D. (2017, October). Ageing in Place, an Overview for the Elderly in Malaysia. In AIP Conference Proceedings (Vol. 1891, No. 1, p. 020101). AlP Publishing.

United Nation Population Division (2014). Population Ageing and Sustainable Development. Popfacts, (2014), 1-4. Retrieved October, 25, 2016 from https://doi.org/ST/ESA/SER.A/290

Van Thanh, P., Tran, D. T., Nguyen, D. C., Anh, N. D., Dinh, D. N., El-Rabaie, S., \& Sandrasegaran, K. (2019). Development of a Real-Time, Simple and High-Accuracy Fall Detection System for Elderly using 3-DOF accelerometers. Arabian Journal for Science and Engineering, 44(4), 3329-3342.

Wong, K. M., \& Musa, G. (2014). Retirement Motivation Among 'Malaysia My Second Home'participants. Tourism Management, 40, 141-154.

Zijstra, G. R., van Haastregt, J. C., Du Moulin, M. F., de Jonge, M. C., van der Poel, A., \& Kempen, G. I. (2012). Effects of the implementation of an evidence-based program to manage concerns about falls in older adults. The Gerontologist, 53(5), 839-849. 